\title{
Javanese Traditional Community Of Natural Preservation In The Central Java Stories
}

\author{
Aloysius Indratmo ${ }^{1}$, Sundari $^{2}$, Prasetyo Adi WW ${ }^{3}$ \\ \{1 ${ }^{\text {aloysiusindratmo@gmail.com; }}{ }^{2}$ sundari@staff.uns.ac.id; ${ }^{3}$ prasetyoadiwisnuwibowo@staff.uns.ac.id\} \\ ${ }^{12}$ Teaching Staff of Regional Literature Study Program FIB UNS
}

\begin{abstract}
Folklore is part of Folklore, which is part of culture that is traditional, informal, and national. One of the functions of Folklore as a folklore is as a "myth" that controls humans to do or to forbid humans to do something. Central Javanese Folklore contains "myths" of nature conservation, such as forests, mountains, plants, rivers, and lakes. As a "myth", this form of human control is conveyed indirectly, through symbols that must be interpreted by the reader. Through hermeneutic reading, it is known that the natural preservation policy of the traditional community of Central Java is conveyed through the symbol that the nature is haunted / wingit, is a kingdom of spirits, and does not uproot plants. Through the symbol of "haunted", "kingdom of spirits" and "not uprooting plants" it is hoped that the reader / community will not damage nature because if it is done it will be what will happen.
\end{abstract}

Keywords: nature, armature / wingit, smooth creatures, revoke

\section{Introduction}

As a cultured society, the traditional people who live in Central Java have a tradition, which is a custom they have inherited from generation to generation. One such tradition is Folk Story which is part of folklore. What is meant by folklore is Indonesian Indonesian folklore Indonesian grammar. This word is a compound word, which comes from two basic words folk and lore. Folk is a group of people who have physical, social and cultural identification characteristics so that they can be distinguished from other groups. These identifying characteristics can include tangible skin color, the same hair shape, the same livelihood, the same language, the same level of education, and the same religion or belief. However, what is even more important is that they already have a tradition, which is a habit they have inherited from generation to generation, at least two generations, which they can recognize as their common property. In addition, they are aware of their own group identity [1]. So folk is synonymous with the collective, which also has the same physical or cultural identification characteristics and has an awareness of personality as a community unity. Lore is a folk custom, that is, part of its culture, which is passed down orally orally or through an example accompanied by gestures or mnemonic devices.

From the description above it can be defined that folklore is a part of a collective culture, which is spread and passed down from generation to generation, among any kind of collective, traditionally in different versions, both in oral form and in examples accompanied by gestures 
or assistive devices. reminder (mnemonic device). As part of folklore, Folklore also has a very important function in human life. According to Bascom [2], folklore has four functions, namely (1) as a projective system, namely as a means of reflecting the imagination of a collective, (2) as a means of ratifying institutions and institutions culture, (3) as an educational tool (pedagogical device), and (4) as a coercive and supervisory tool so that community norms will always be obeyed by their collective members.

In its function as a coercive and supervisory tool so that community norms are always obeyed by its collective members, folklores convey many "myths" that control the community to do or not do something, including doing or not doing something to preserve nature. It is very interesting to examine what "myths" conveyed in Central Javanese Folklore to preserve nature. Is there any natural conservation policy that is still relevant if applied today?

Many understandings from experts who try to define what the meaning of hermeneutics, including the following [3]. First, Sumaryono in his book, explained that etymologically, the word "hermeneutic" comes from the Greek hermeneuein which means "to interpret", and from this hermeneuin the word can be drawn hermeneia which means "interpretation" or "interpretation" and the word hermeneutes which means interpreter [4]. Second, according to Nurcholis Madjid, quoted by Fahruddin Faiz hermeneutics is the understanding or giving understanding of textual facts from sacred sources (Scripture or something that is 'pure') in such a way, so that what is shown is not only just the physical meaning of the words of the sacred text, but even more the "inner meaning" (inner, "inward meaning") they contain. Third, according to Zygmun Bauman as quoted by Fahruddin Faiz, hermeneutics is "an attempt to explain and trace the message and basic understanding of an unclear, blurry, dim, and contradictory speech or writing that causes confusion for listener or reader "

From some of the definitions above it can be concluded, that hermeneutics has three meanings, namely first: the science of interpretation; second: the knowledge to know the purpose contained in the words or expressions of the author, and third: interpretation specifically refers to the interpretation of the scriptures.

\section{Research Method}

This research examines known and lived Folklore in Central Java society. Some of the folklore titles have been collected in two books. The first book was titled Central Javanese Folklore by Suryo Handono and friends. The second book is entitled Blora's Central Javanese Folklore written by Tri Wahyuni and friends. These two books are the sources of this research data. The technique of collecting data uses the content study technique. Data analysis uses Hermeneutics theory.

\section{Results And Discussion}

\subsection{Nature in Central Javanese Folklore}

As usually the case with stories, Folklore originating from the Central Java region also always presents characters who live their lives and lives throughout the story. The characters interact with one another. Interaction between the figures often lead to conflict. This conflict is one of the attractions of folklore. The characters in folklore live in a certain place, some characters live in a certain kingdom, in a certain village, on a mountain, on the bank of a river, 
and there are even figures who live in the forest. In other words, the characters inhabit the universe.

Central Javanese Folklore tells nature in several parts, including forests. Forest is an area that is overgrown with thick trees and other plants. One of the forests told by the Central Javanese Folklore is a forest near Nusakambangan. Central Javanese Folklore describes it as follows:

"Ancient times in the southern coast, near Nusakambangan, are still dense and swampy forests. In that place there are still many wild animals that are free to roam. Around the area there is a "demon kingdom" called the Nusatembini Kingdom. This kingdom has a vast territory, stretching from east to west [5]. "

The quote from the Central Javanese Folk Story entitled "The Kingdom of Nusatembini" above tells the dense and swampy wilderness near Nusakambangan. It can be imagined, that the jungle is full of big trees, the atmosphere is very dark because the sun's rays cannot penetrate the lush leaves. Because of the dark atmosphere, the forest is known as the kingdom of stealth, where spirits live.

To establish a kingdom or duchy or a village, people must cut down the trees in the forest or it is referred to as clearing forests. The establishment of the Donan Duchy is related as follows:

"In the past, the Donan area was known as an area which was mostly wilderness and full of swamps. This area is known as a dangerous area because there are still many wild animals that roam freely. At the end of the XIV century, several groups of people who cleared the forests began to arrive. One of the community groups is a group from Banyumas led by Raden Ranggasengara and Adipati Mrapat, Adipati Wirasaba's son-in-law. "

In clearing forests to establish settlements or kingdoms, people not only cut down existing trees, but also drive out stealth who have already lived in the forest. Not all demons are willing to leave their places so often they have to be driven out by force, by war. Sometimes there are also many human victims who try to open the forest into villages [6].

The forest is also a place to find firewood as did Timun Mas and his mother. Jaka Tarub also went to the forest to hunt animals. In the forest there is also a clear lake where the nymphs bathe. That's where Jaka Tarub met with Nawangwulan nymphs [7].

The clearing of forests for settlements is also complemented by the opening of rice fields or fields. Rice fields are land that is tilled and irrigated for planting rice. For this purpose, paddy fields must be able to support standing water because rice requires inundation at certain periods of growth. To irrigate paddy fields, irrigation systems from springs, rivers or rainwater are used. It was in the rice fields that Jaka Tarub farmed, planted rice to support his life [8]. All the rice is not directly eaten but all is stored in the granary.

If the land is dry, lacking water, then fields or tegal or gardens are planted with seasonal crops such as crops or horticulture. In this field Mbok Rondha Dhadhapan planted cucumber seeds which later produced a large fruit that turned into a baby Timun Mas.

In addition to rice and cucumber, Wijaya Kusuma flowers also grow in a luminous, very beautiful, and very fragrant smell. Whoever has this very magical flower will all his descendants become kings. Wijaya Kusuma flowers only grow on Majeti Island or on Nusakambangan Island on the southern coast, Cilacap Regency, Central Java.

Ketapang trees also grow which are often used to perch manuk Give so that eventually the tree grows crooked. There is also a Roasted tree, where the Santri Undhig skullcap is stuck [9]. There is also an orange tree with very thick fruit. Santri Undhig then picked the orange and ate it. It turned out to be very sweet (Javanese: legi). Therefore, the place was then given the name Jeruk Legi. 
Apart from forests, the part of the universe that appears in many folklore is the mountain. Mountains are part of the earth's surface that stands out / towers higher than the surrounding area . Mount Tidar was created by the gods as a "nail" that made the island of Java stable. Syahdan, once upon a time the land of Java was still a wilderness where no one dared to live there. Most of Java was once controlled by various spirits. It is said that the land of Java which is surrounded by the sea is like a boat that is easily swayed by large ocean waves. So seeing that the gods immediately find a way to overcome them. So the gods gathered to discuss the issue of the Land of Java which was never calm by the waves. Sent a number of gods to calm the island.

They brought a number of troops to the west of Java. However, suddenly the island of Java was shaken again and biased because the gods and armies only occupied the western region. To be balanced, some are sent east. But this effort still failed. Seeing that reality, the gods are busy looking for a solution. After some time of deliberation, a brilliant idea was obtained. Inevitably the gods must create a giant nail, and the nail will be driven in the center of the Land of Java, which is the middle point that can make the island of Java balanced. And the giant nail that was planted was said to be believed to be part of the community as Mount Tidar.

As with forests, mountains are haunted places. Not all people dare to live in the mountains, only those who have supernatural powers are brave, like the priests. This priest lived in Mount Burangrang. The mountain is also an ascetic place, as did Klinthing's new father. Therefore, Klinthing had to catch up with the mountain to be able to meet his father.

According to Folklore, the mountain was built by the gods in secret and overnight. But not all the mountain construction was successful. In the Kebumen area, the gods did not succeed in creating a mountain because its secret work was known by a girl. Then it is not a mountain that is created but only a hill. The people call that hill Mount Wurung meaning a failed mountain [10].

On the south coast of Central Java there is a cave overlooking the sea. Goa is a natural hole in a cliff or land that is quite large and deep. The cave in question is the Karangbolong Cave. This cave is haunted because it is guarded by Dewi Suryawati, servant of Ni Dewi Loro Kidul. In this cave there are many swallow's nests that can be used as medicine. Thanks to this swallow's nest concoction, King Empress Kartasura was successfully healed from the illness he suffered.

Another part of nature is lake or swamp. Central Javanese Folklore tells of the creation of the Lake Rawa Pening as a disaster that sank a village with all its inhabitants. Once upon a time, a new Klinthing incarnation child came to a village that was partying. The boy's body was covered in wounds so it smelled fishy. Because of starvation, the child asked for food but no one gave, even he was expelled from the party. The boy then made a competition to pull the stick that he plugged into the ground. Because no one can pull out the stick, the child himself will pull it out. From the place where the ladi was pulled, a flood was unstoppable until it inundated the whole village. The village then turned into a lake of Rawa Pening [11].

The river is also a part of nature that is told in Central Javanese Folklore, one of which is the Luk Ulo River. On the banks of the river lives Mbok Rondha Sembiga. His livelihood is fishing in the river and gardening. He is next door to Mbah Laran who is very powerful. Mbah Laran also lived by fishing in the river.

Another part of nature that is told in Central Javanese Folklore is lake or lake or also called swamp. One of the ponds or swamps is Rawa Pening, which is a natural lake in Semarang Regency, Central Java, with an area of around 2,670 hectares occupying the areas of Ambarawa, Bawen, Tuntang, and Banyubiru Districts. Rawa Pening is located in the lowest 
slope of the slopes of Mount Merbabu, Mount Telomoyo and Mount Ungaran. According to legend, the occurrence of Rawa Pening is a disaster and punishment for villagers whose actions have offended the character of Baru Klinthing.

\subsection{Policies on the Conservation of Javanese Traditional Communities}

Folklore is the response and understanding of society to nature and events that occur around him. In traditional societies the response to natural events is simply described. This is in accordance with his cultural background which is also still simple. For example, traditional Javanese people understand earthquakes as a result of the dragons that support the earth in motion. The rationality is simple, because the dragons that support the earth sway or move, the earth on it also moves, that's the earthquake. The simplicity of rationality produces policies that are also of a simple nature [12].

Nature for traditional communities, not only serves as a place to live, but also functions as a provider of life and shelter. Therefore nature is very meaningful to society. Because of its important position, nature must be preserved with a variety of policies. It's just that in the folklore the nature preservation policy is not mentioned directly but rather disguised or implied in the storyline or in the form of symbols.

The policy disguised in the Central Javanese Folklore for the preservation of nature includes: nature is told as haunted or winged. For example the forest in Nusatembini is a very dense forest, wingit and very haunted. Haunted forests are also described as the kingdom of stealth. Told as a haunted stealth kingdom, the people did not dare to come and destroy the forest. People are afraid of facing demons who can harm or kill them. Then the forest is still alive and sustainable and well developed. This is a form of nature conservation policy that is expressed indirectly in folklore.

The nature of "haunted" or "wingit" is not only embedded in the forest, but also in other parts of nature. Mountains, rivers are also told as haunted. Thus people will also be afraid of mountains and rivers so that they do not damage it.

Spirits or ghosts also sometimes guard special natural objects in the forest, such as flowers. Central Javanese Folklore tells the story that Bunga Wijaya Kusuma has very powerful properties, but Bunga Wijaya Kusuma only grows in certain places and is guarded by spirits as well. Guardians of nature besides spirits are also wild animals. People are afraid of wild animals so they don't touch them.

Nature conservation will be realized if the community does not uproot the plants. This is told indirectly in the Legend of Rawa Pening. In this story plants are symbolized by sticks planted by the single child. When the stick was pulled out there was a flood and submerged the village where they lived. Symbolically and indirectly this story conveys a policy of not pulling plants / plants because it will cause floods [13].

\section{Conclusion}

Nature for traditional communities, not only serves as a place to live, but also functions as a provider of life and shelter. Therefore nature is very meaningful to society. Because of its important position, nature must be preserved with a variety of policies. Some of the natural conservation policies of traditional Javanese society are that nature is told as haunted or wingit, guarded by spirits, many wild animals, and do not damage / uproot existing plants. 


\section{Refferences}

[1] A. Dundes, Interpreting Folklore. Bloomington: Indiana University Press, 1965.

[2] W. Bascom, Four Functions of Folklore, no. 1. Englewood Cliffts: NJ Prentice, 1965.

[3] F. Faiz, Hermeneutika Al-Qur'an Tema-Tema Kontroversial, vol. 12 Suppl 1, no. 9. Yogyakarta: Elsaq Press, 2005.

[4] E. Sumaryono, Hermeneutika: Sebuah Metode Filsafat. Yogyakarta: Kanisius, 1999.

[5] D. Suryo Handono, Cerita Rakyat Jawa Tengah. Semarang: Balai Bahasa Provinsi Jawa Tengah, 2013.

[6] Abdullah, I. Konstruksi dan Reproduksi Kebudayaan. Yogyakarta: Pustaka Pelajar, 2015.

[7] Ahimsa-Putra, H. S, ed. Masyarakat Melayu dan Budaya Melayu dalam Perubahan. Yogyakarta: Adicita Karya Nusa, 2007.

[8] Ahimsa-Putra, H. S. Antropologi Koentjaraningat: Sebuah Tafsir Epistemologis. Yogyakarta: Yayasan Obor, 1997.

[9] Ayatrohaedi. Kepribadian Budaya Bangsa (local Genius). Jakarta: Pustaka Jaya, 1986.

[10] Hari Bakti Mardikantoro. "Bahasa Jawa sebagai Pengungkap Kearifan Lokal Masyarakat Samin di Kabupaten Blora". Jurnal Komunitas 5 (2) (2013): 197-207. http://journal.unnes/ nju/index.php/ komunitas, 2013.

[11] Hendrosaputro, W. dan Abdullah, W. "Kearifan Lokal dalam Bahasa Jawa Orang Samin di Kabupaten Blora". Jurnal Penelitian Fundamental UNS, 2010.

[12] Sutopo, H.B. Metode Penelitian Kualitatif. Surakarta: Penerbit Universitas Sebelas Maret, 1986.

[13] S.T. Widodo and K. Saddhono. "Petangan Tradition In Javanese Personal Naming Practice: An Ethnoliguistic Study." GEMA Online ${ }^{\circledR}$ J. of Lang. Stu. vol. 12 no. 4 pp 1165-1177, 2012 